\title{
Past and present state of the ichthyofauna of Lake Lugano
}

\author{
Rudolf Müller and Hans Jürg Meng \\ Swiss Federal Institute for Water Resources and Water Pollution Control (EAWAG), \\ $\mathrm{CH}-6047$ Kastanienbaum
}

Key words: Fish fauna, zoogeography, eutrophication, fish introductions, lake fishery, fish stock assessment, hydroacoustics, Lake Lugano (Lago di Lugano).

\begin{abstract}
The evolution of the ichthyofauna of Lake Lugano (Lago di Lugano) during the past 120 years is characterized by the introduction of eight new fish species and by the possibly natural addition of the blenny (Blennius fluviatilis) in recent years. Introduced Salmonids such as charr (Salvelinus alpinus) and whitefish (Coregonus sp.) have established strong populations during the first half of this century, but have declined drastically thereafter. Likewise, the population of the native shad (Alosa fallax lacustris) has diminished significantly. A hydroacoustic survey of the pelagic fish stock of Lake Lugano in 1989 revealed the presence of a dense bleak (Alburnus albidus) population at 0 to $14 \mathrm{~m}$ depth. No other fish were found to be present in the pelagic zone. Oxygen and temperature distributions seem to confine the bleak to the uppermost layer in summer. In winter, very few fish were located by echosounding. Growth of bleak and roach (Rutilus rubilio) was difficult to interpret since data for comparison are lacking. Growth of perch (Perca fluviatilis) in the littoral zone was found to be slower than in other eutrophic lakes, for no obvious reason. Possible ways of restructuring the pelagic fish community are discussed.
\end{abstract}

\section{Introduction}

Lake Lugano is one of the two large Insubrian lakes shared by Italy and Switzerland (Canton Ticino), the other one being Lake Maggiore. Both lakes are of glacial origin and belong to the Po drainage area. The particular geographic situation of these lakes, on the south of the big alpine watershed, leads one to expect a fish fauna distinctly different from the one in the lakes north of the Alps. The original fish species composition of a particular drainage area is primarily a function of the zoogeographic situation of that area (Tonn 1990). Berg $(1933,1948)$ allocates the region south of the Alps to the Rhodano-padanic transition district within the Mediterranean subregion. Fossils from the early Tertiary indicate that the area of today's Central Europe, including Northern Italy, once held a fairly uniform fish fauna. During the Tertiary, about 20 to 30 million years ago, this area became separated in two regions by the rising Alps. In the course of the Quaternary, the fishes in the two regions started to differentiate to some degree (Steinmann 1948). It is 
therefore not surprising to find a number of fish species south of the Alps that are analogous to species in the north, or to find species that occur on one side of the Alps only.

This paper consists of two parts. In Part I we attempt to review the development of the ichthyofauna of Lake Lugano in the course of the past 120 years based on information from the literature. In Part II, some quantitative considerations on today's fish stocks (commercial yield, distribution in the lake, biomass, growth) that emerged from a recent survey of Lake Lugano are given. These considerations may eventually be implemented in the management and conservation of the fishes of the lake.

\section{The fish fauna of Lake Lugano in the 19th and 20th century}

Table 1 provides a synoptic view of the fish species inhabiting Lake Lugano in the past and today. The terminology used was adopted from Pedroli et al. (1991).

The most detailed information on the fish in Lake Lugano in the 19th Century was compiled by Pavesi (1871-1872). His description of the fish species is largely based on earlier authors such as Schinz (1836), De Filippi (1844), Monti (1846, 1864), Heckel \& Kner (1858), Lavizzari (1859-1863) and Canestrini (1865). A similar account on the fish in Canton Ticino was given by Fatio (1882-1890).

In the beginning of the 20th Century, Ghidini (1910), basing himself largely on Pavesi's (1871-1872) work, reports on the first introduced fish species in Lake Lugano. Later, Fuhrmann \& Pelloni (1938), Antonini (1948), and Steinmann (1936, 1948) describe the fish fauna of the lake. The most recent and thorough treatment of the fish in Lake Lugano has been given by Pedroli et al. (1991). This work traces the evolution of the ichthyofauna during the past forty years. The catch statistics (Fig. 1) provide an indication of the amount of fish caught in Lake Lugano during the past decade.

Changes in stock size and composition can be deduced from Table 1 and Fig. 1. Of particular zoogeographic interest are the analogous species and subspecies inhabiting Lakes Lugano and Maggiore, with their corresponding counterparts living north of the Alps: shad ("Agone"), corresponding to the extinct allis shad Alosa alosa (L.) in the Rhine basin, the two southern Barbus species versus barbel Barbus barbus (L.), the southern bleak "Alborella" versus Alburnus alburnus (L.), two Rutilus species ("Pigo", "Triotto") versus roach Rutilus rutilus (L.), "Savetta" versus nose carp Chondrostoma nasus (L.), and finally "Strigione" versus Leuciscus souffia agassizi Cuv. \& Val. Two Swiss fish species occur south of the Alps only: the goby "Ghiozzo" and the blenny "Cagnetta". The latter was recorded in Lake Lugano for the first time in 1985 (Pedroli et al. 1991). Recently, the catch of a European catfish (Silurus sp.?) and of a sturgeon (Acipenser sp.) from Lake Lugano have been reported (B. Polli, pers. com.). Both specimens must originate from stocked fish because the sturgeon, a rare species in Lake Maggiore already in earlier centuries, never reached Lake Lugano (Kaufmann 1960). Silurus is not native to the Mediterranean subregion.

Lake Lugano has been the laboratory for uncontrolled introduction of almost any fish species that might hold commercial value. Thus, the changes in the species 


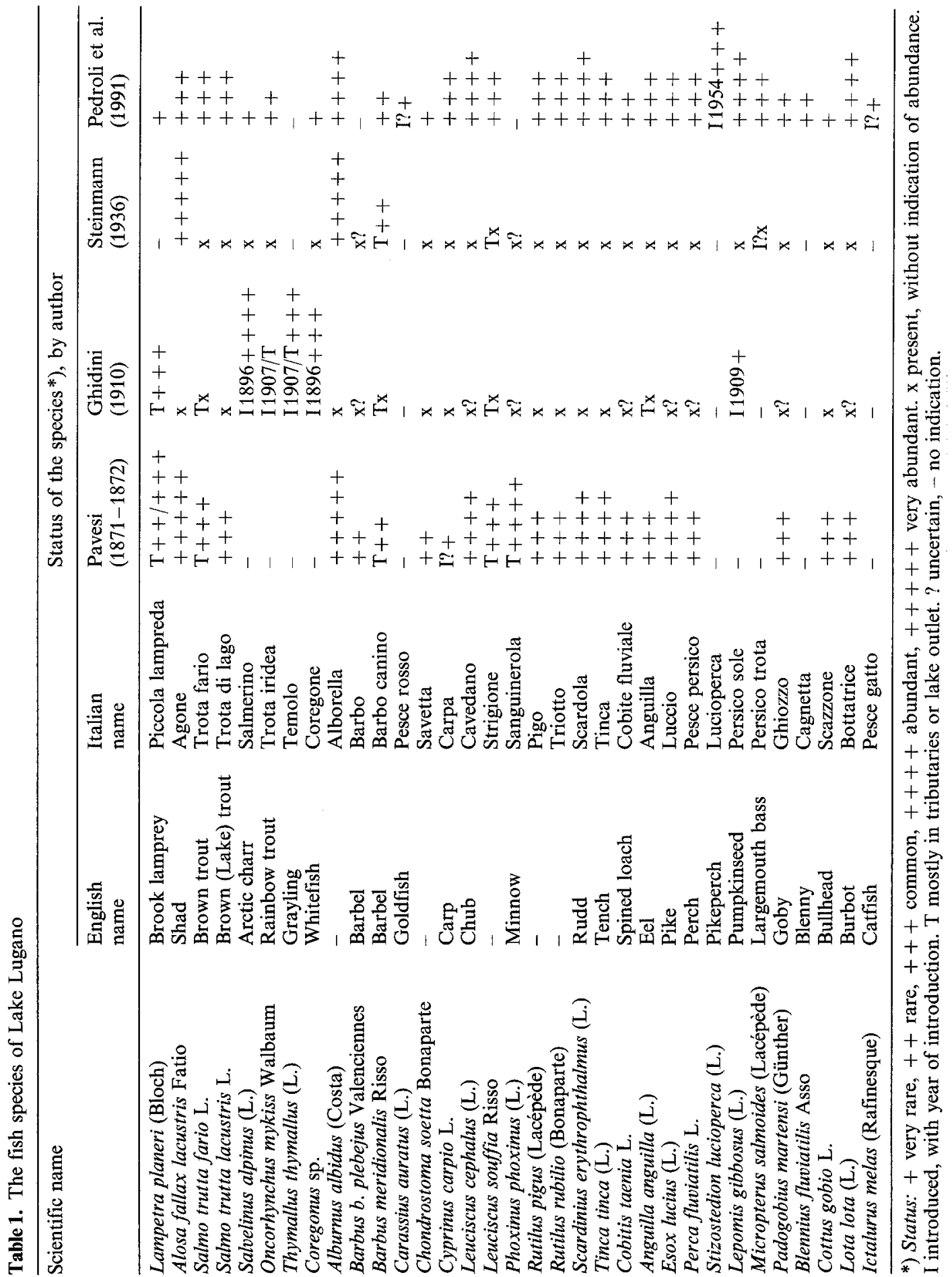



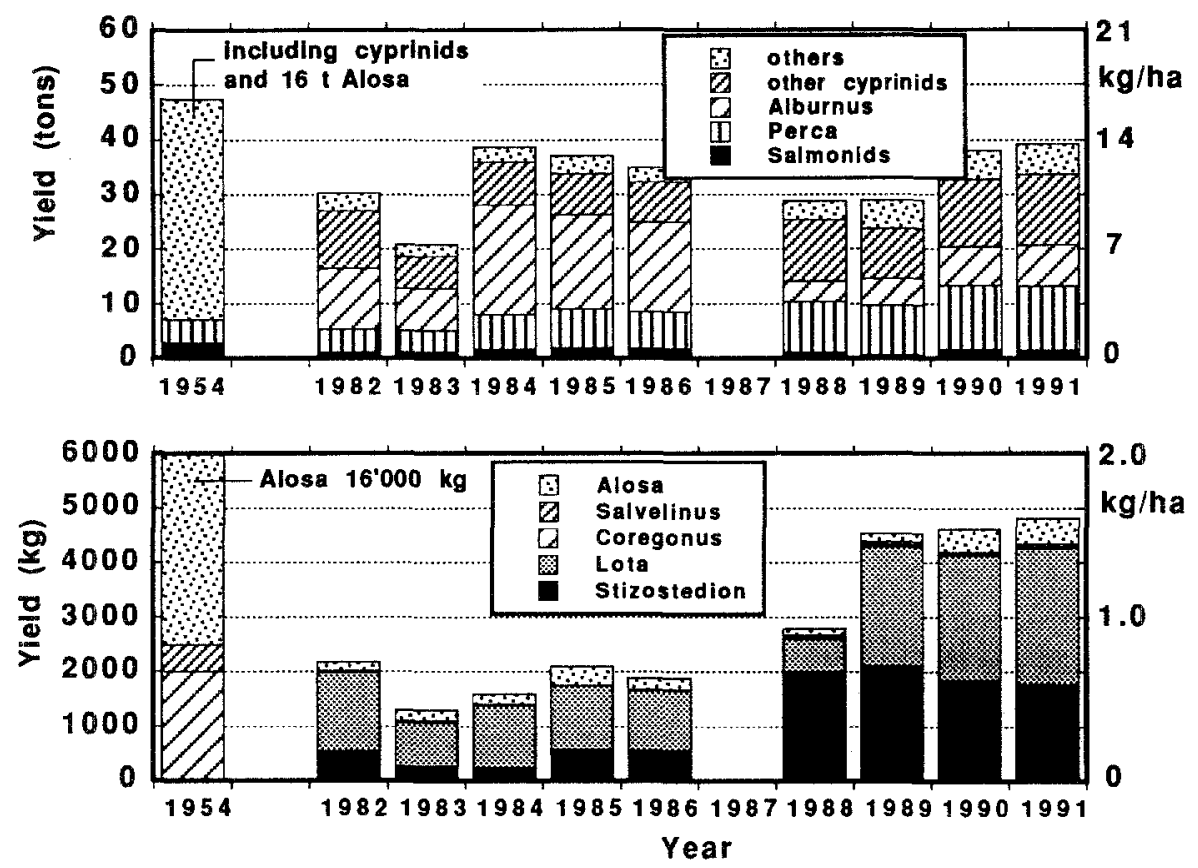

Figure 1. Above: total annual yield in 1954 and 1982-1991 of the commercial fishery in the Swiss part of L. Lugano. Fishing banned in 1987 and first half of 1988. In 1954, 69\% of salmonids were whitefish, in 1982-1991, $97 \%$ were trout. Below: yield of selected species

composition of the ichthyofauna of Lake Lugano during the past 120 years are largely the result of introductions. Unfortunately, the ecological requirements of the new species and the risks of such introductions have almost never been analyzed. Today, Lake Lugano still holds 21 of the 23 species described by Pavesi (1871-1872, see Table 1). Barbel and minnow were not recorded in 1991 but most likely still occur. The blenny is thought to be present due to natural causes. Eight other fish species were added by man: Arctic charr, rainbow trout, whitefish, goldfish, pikeperch, pumpkinseed, largemouth bass, and American catfish. Most of the introductions were made around or shortly after the turn of the century. The pumpkinseed, for example, was introduced in 1909 , with the hope of adding a profitable element to the percid fishery. However, this fish did not grow well, it reproduced rapidly and soon became a nuisance to the fishery. Today the pumpkinseed is still present, although in relatively low numbers.

Significant quantitative changes in the fish stocks of Lake Lugano have been recorded since about 1950. The populations of shad and of the introduced whitefish and charr, once the basis of the commercial fishery, have strongly declined. In contrast, the cyprinids are thriving. These changes have most likely been brought about by the deteriorating state of the lake (Barbieri et al. 1989). It is not surprising that those fish species which are most sensitive to environmental degradation caused by eutrophication were most seriously affected. Most likely, the size of the salmonid 
stocks will continue to depend on stocking unless phosphorus concentrations in the lake are changed enough to change the trophic state of the lake (Müller 1992).

Massive mortalities of shad already occurred around 1900 (Heuscher 1905), and again around 1940 (Baldi et al. 1948). The cause of these mortalities remains obscure. The shad population recovered somewhat in the 1950s but is low today. Nevertheless, the shad does not seem to be on the verge of extinction because it has managed to survive the period of maximum eutrophication between 1975 and 1980 through natural reproduction. Fishing yields indicate that the shad population is stable today (Fig. 1). However, management measures aimed at enhancing the stocks of this threatened native species may face the problem of low public acceptance because the shad is considered to be an egg predator (Pedraita 1956) and because it is of little commercial value. The marked natural recovery of the shad population in Lake Maggiore, in the presence of a strong whitefish stock (Grimaldi 1992), is likewise met with anxiety by the local fishermen (B. De Bernardi, pers. com.).

\section{Quantitative assessment of the Lake Lugano fish stocks}

Due to the severe radionuclide contamination of the fish of Lake Lugano following the Chernobyl incident in April 1986, the Swiss Government imposed a fishing ban on the Swiss parts of Lake Lugano from September 3, 1986 to July 9, 1988. Because knowledge of the fish stocks in the lake was poor and more information was needed for management, the Canton Ticino contracted EAWAG to conduct a stock assessment (EAWAG 1990). The aim of the study was to describe the fish distribution and biomass per species in summer and winter after the period of reduced fishing pressure (there was no fishing ban in the Italian part of the lake). The growth of selected species was analyzed as well. Thus, this study represents the most comprehensive attempt undertaken so far to characterize the fish populations in Lake Lugano. A second task, the evaluation of the effect of reduced fishing on the fish community, had to be postponed until later because no reference for the fish stock size and composition before the fishing ban was available.

\section{Methods}

Two stock assessment campaigns using echosounding and pelagic trawling were conducted: one in February 1989 for the winter situation, and one in September 1989 for the summer situation. Echosounding during day and night was done along parallel transects spaced $1 \mathrm{~km}$ apart. The echosounder used was a Type 101 (BioSonics Inc., Seattle), $420 \mathrm{kHz}$ dual beam sounder with beam angles of $6^{\circ}$ and $15^{\circ}$, respectively (Ehrenberg 1984). The range was 1.25 to $125 \mathrm{~m}$, with a vertical resolution of approximately $0.6 \mathrm{~m}$. The dual beam system allows estimation of both fish size and biomass. A small-meshed midwater trawl (Gjernes 1979) was used to verify the species and size distributions of the fish detected. Further data on fish growth was provided by AQUARIUS Consultants, Neuchâtel, who sampled the benthic-littoral fish with gillnets (10-55 mm bar mesh size) in summer 1989 under a contract with Canton Ticino. 


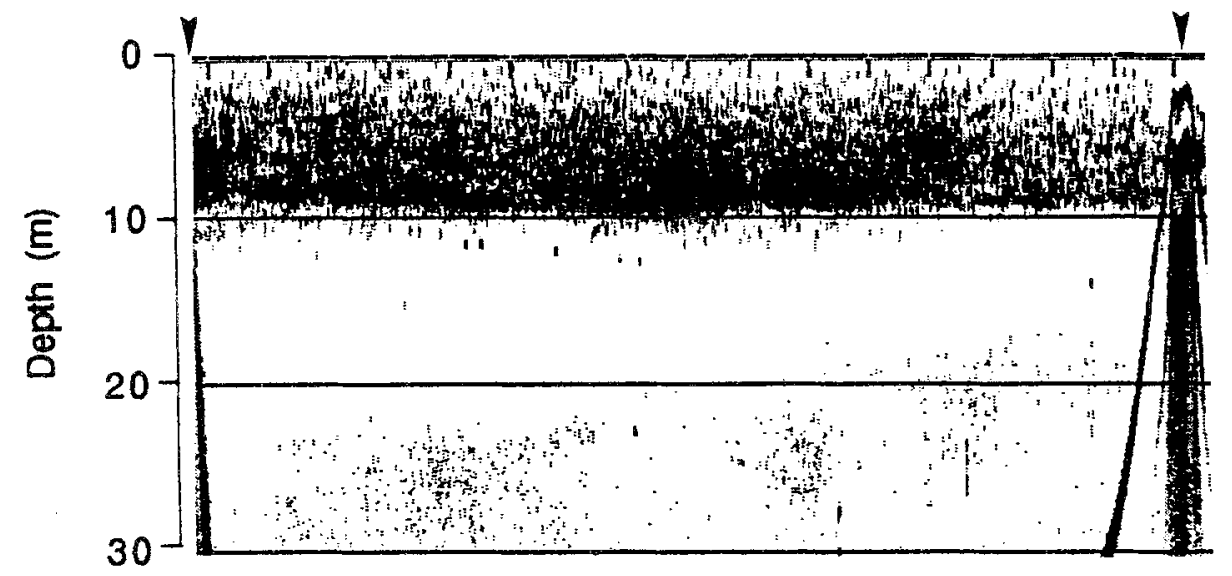

Figure 2. Echosoundings from South Basin of L. Lugano between Morcote (left arrow) and Porto Ceresio (right arrow), September 6,1989, at night. Fish targets (exclusively bleak) are limited to a depth range of $0-12 \mathrm{~m}$

\section{Results and discussion}

\section{Fish distribution}

In February, very low fish densities were found in all parts of the lake, except for a near-shore area off San Mamete in the North Basin where 56 bleak of 96-142 mm total length were caught by trawling. Thus, the distribution of fish biomass could not be established. The few fish located by echosounding were scattered over a depth of 2-80 $\mathrm{m}$ in the South Basin and 2-120 $\mathrm{m}$ in the North Basin.

In September, extensive aggregations of fish were located between the surface and approximately $14 \mathrm{~m}$ depth (Fig. 2), with practically no fish in the deeper zones. All of the more than 10000 fish caught in 12 trawl hauls in the pelagic zone were - without exception - bleak. The horizontal distribution of fish biomass in summer is shown in Fig. 3.

In the North Basin, fish were located primarily in near-shore areas along the whole shore-line, except for the eastern parts near Porlezza. Large aggregations were found off Osteno and near Campione-Bissone. In the South Basin, fish were located exclusively between Carabietta and Poiana, with a dense aggregation north of Brusino-Arsizio. The terminal parts of Capolago and Agno appeared to be void of fish.

The depth distribution (Fig. 4) of the fish in September indicates that the maximum of the relative fish density in the South Basin at $6 \mathrm{~m}$ depth was twice as high as in the North Basin where the maximum density was at $4 \mathrm{~m}$ depth. Maximum depth of fish was $14 \mathrm{~m}$ in the North Basin and $12 \mathrm{~m}$ in the South Basin. The well-defined lower limit of fish occurrence in both basins (Fig. 2) suggests that certain environmental parameters might be the cause of this type of fish distribution. The metalimnetic oxygen concentration minimum, a phenomenon typical for eutrophic 


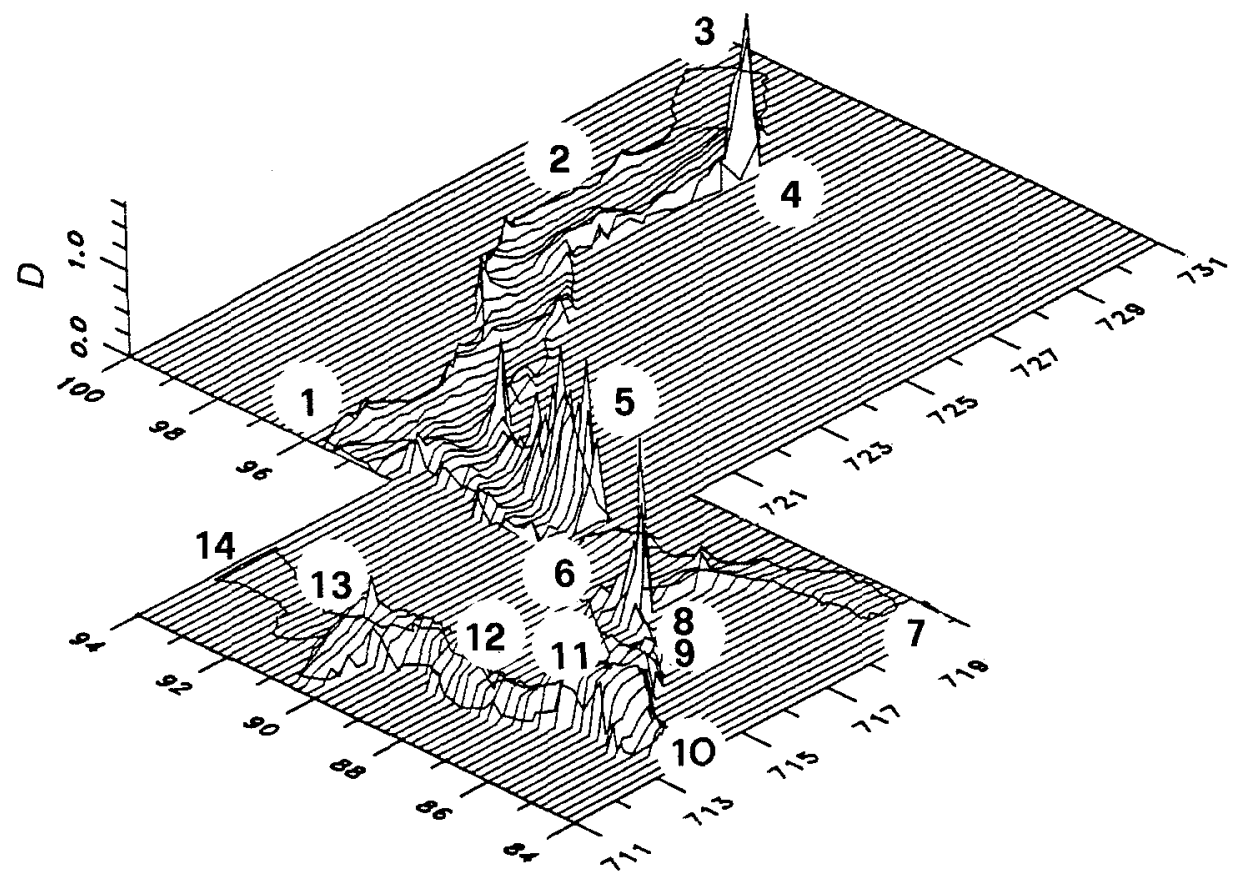

Figure 3. Relative fish density D (biomass/unit area) in L. Lugano in September 1989. Coordinates in kilometers refer to the Swiss Topographic System. 1 Lugano, 2 San Mamete, 3 Porlezza, 4 Osteno, 5 Campione-Bissone, 6 Melide, 7 Capolago, 8 Poiana, 9 Brusino-Arsizio, 10 Porto Ceresio, 11 Morcote, 12 Figino, 13 Carabietta, 14 Agno

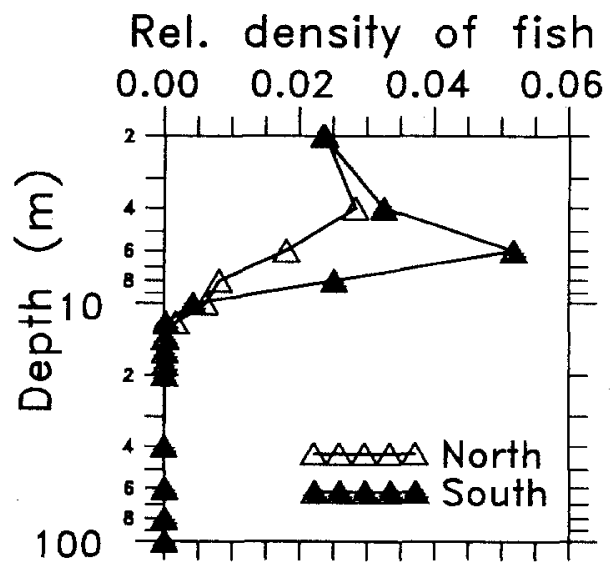

Figure 4. Vertical distribution of the relative fish density (biomass/volume) in the North and South Basins of L. Lugano in September 1989, at night 

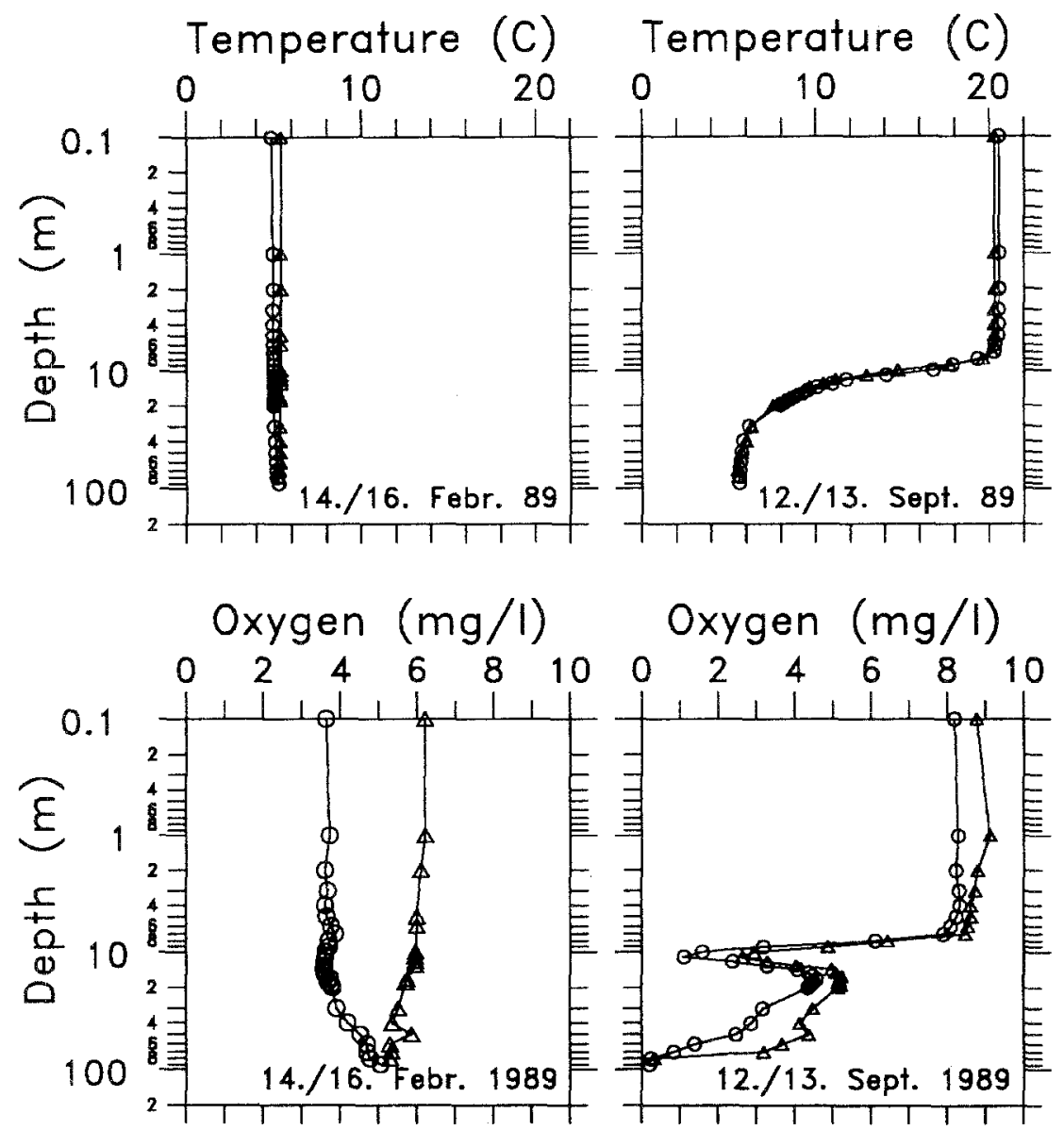

Figure 5. Temperature and oxygen profiles in the South Basin of L. Lugano in February 1989 (left) and September 1989 (right), at Melide (triangles) and Figino (circles). Data from Canton Ticino (LSA 1990)

lakes, resulted in oxygen concentrations of $1 \mathrm{mg} \mathrm{O}_{2} 1^{-1}$ at $10 \mathrm{~m}$ depth in the South Basin, and of $5 \mathrm{mg} \mathrm{O}_{2} 1^{-1}$ at $15 \mathrm{~m}$ depth in the North Basin (Fig. 5). In both basins, oxygen concentration reached zero at about $80 \mathrm{~m}$ depth. The thermocline was between 8 and $20 \mathrm{~m}$ depth in both basins. We conclude that the fish distribution primarily reflects temperature distribution, the warm surface waters being strongly preferred by the bleak. Low oxygen values at depths greater than $10 \mathrm{~m}$ in the South Basin might explain the absence of fish in the deeper zones. In addition, the distribution of food and light is expected to play an important role in the vertical distribution of the fish. 


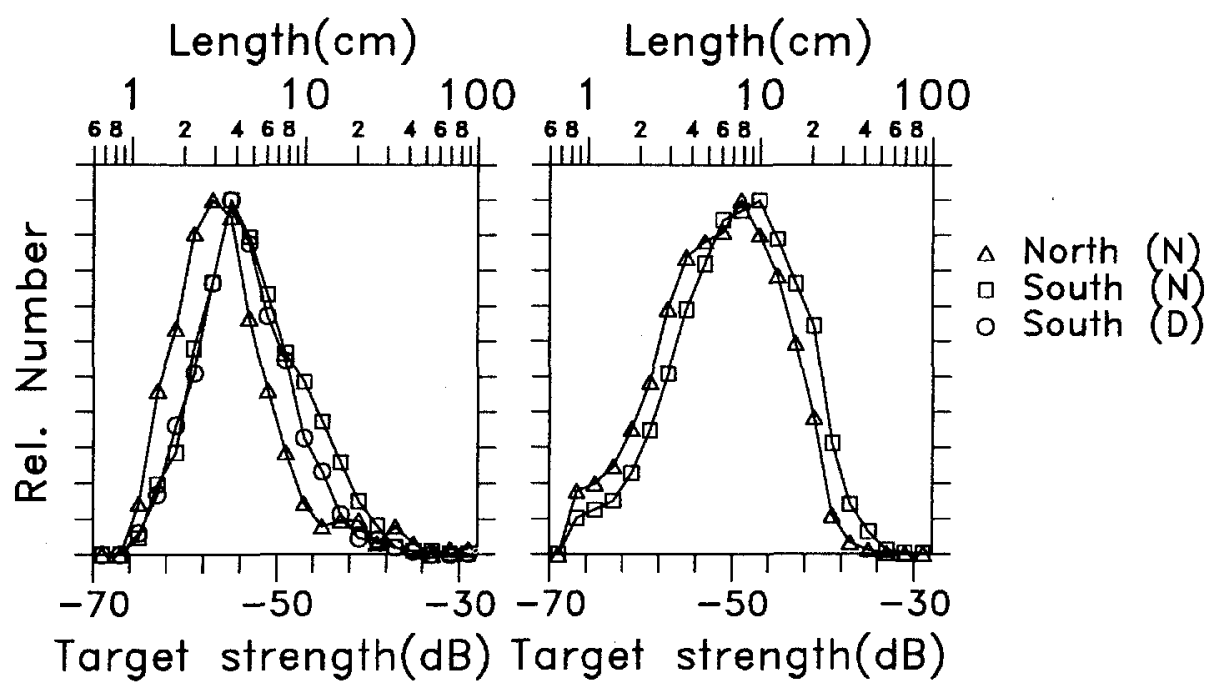

Figure 6. Size distribution of fish in L. Lugano as recorded by echosounding in February 1989 (left) and September 1989 (right). D day, N night

\section{Fish size}

The size structure of the pelagic fish stock allows to conceive, to some degree, the structure of the plagic food chain. Fig. 6 shows the size distribution of the fish located by echosounding. Mean acoustic size (target strength TS in dezibel dB) was converted to fish length by the method of Love (1977). In winter, mean target strength corresponded to a mean fish length of $3-4 \mathrm{~cm}$ in both basins, with relatively few fish between 10 and $30 \mathrm{~cm}$ length. In summer, mean target strength corresponded to 8 -$10 \mathrm{~cm}$ fish length, with significantly more fish between 10 and $30 \mathrm{~cm}$ than in winter. Small fish of $2-3 \mathrm{~cm}$ length are likely to be underrepresented in this graph because single fish targets are difficult to detect in dense schools of such small fish. A comparison of acoustic size and true size (Fig. 7) shows good agreement. Most fish were 40 to $120 \mathrm{~mm}$ long, with few fish larger than $120 \mathrm{~mm}$. Large numbers of youngof-the-year bleak ( $21-22 \mathrm{~mm}$ long) were caught at a depth of $10-13 \mathrm{~m}$. These young fish had not formed any scales yet.

\section{Growth}

In fish of comparable genetic constitution, growth reflects the overall quality of the environment. Food abundance and availability, and stressors such as, e.g., temperature, oxygen and competition largely control growth. Therefore, the growth curves by year class in Figs. 8 and 9, based on data from gillnet and trawl catches, allow conclusions to be drawn on the suitability of the environment for the fish species studied. 

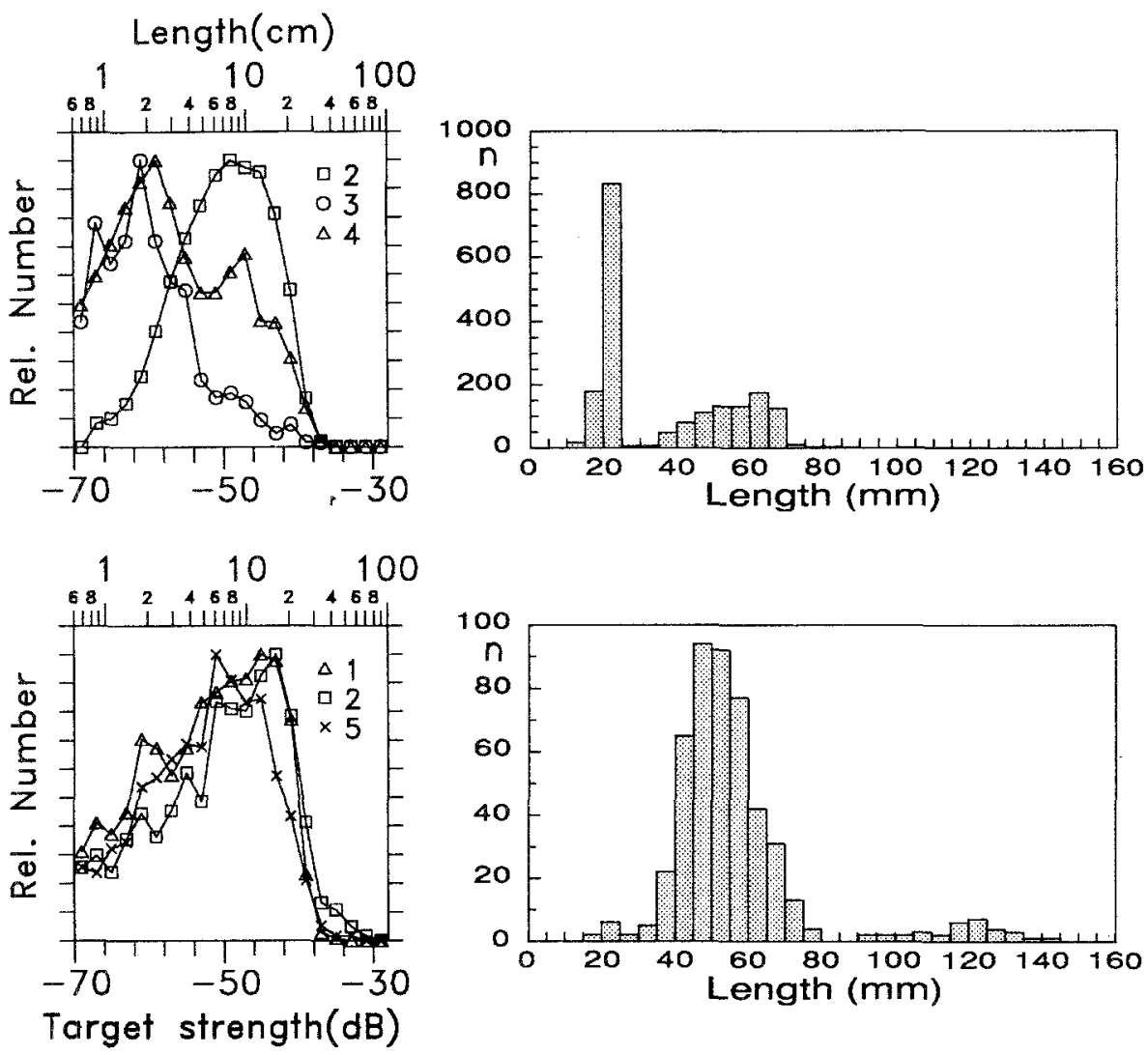

Figure 7. Length frequency distribution of fish in L. Lugano, September 1989, at night. Above: North Basin, fish size by echosounding during trawl hauls 2 to 4 (left), and true length of combined fish (bleak) from trawl hauls 2 to 4. n sample size. Below: South Basin, fish size by echosounding during trawl hauls 1,2 and 5 (left), and true length of combined fish (bleak) from trawl hauls 1,2 and 5. n sample size

Bleak (Fig. 8) grew very slowly in the first year, reaching approximately $25 \mathrm{~mm}$ at age 1. Because scale formation appeared to take place during the second year only, scale reading in bleak systematically underestimates age by at least one year (e.g. Giussani \& Ruffoni 1985) if this fact is not taken into account. Maximum length was approximately $160 \mathrm{~mm}$. Due to the lack of other reliable growth data, no comparison with bleak populations in other lakes could be made. Length frequency distributions from trawl catches indicated that the population in Lake Lugano was dominated by fish up to age three. The vast majority of the bleak caught by commercial gillnetting $(10-13 \mathrm{~mm}$ mesh size) are $10-13 \mathrm{~cm}$ long and three to six years old. The fact that natural reproduction is highly successful points to almost ideal conditions for bleak in this lake.

Roach ("Triotto", Fig. 9) appeared to reach a maximum length of $180-200 \mathrm{~mm}$ at the age of more than seven years. Growth was slow compared to Rutilus rutilus 

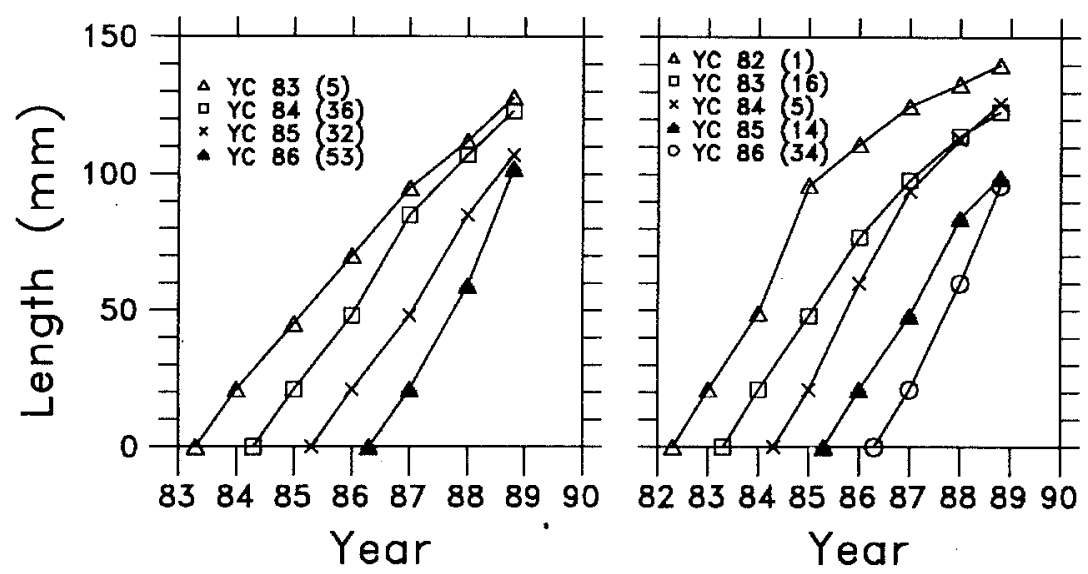

Figure 8. Growth of bleak in the North Basin (left) and the South Basin (right). Mean length at full years except 1989, year classes 1983-1986 and 1982-1986, respectively. Numbers in brackets indicate sample size

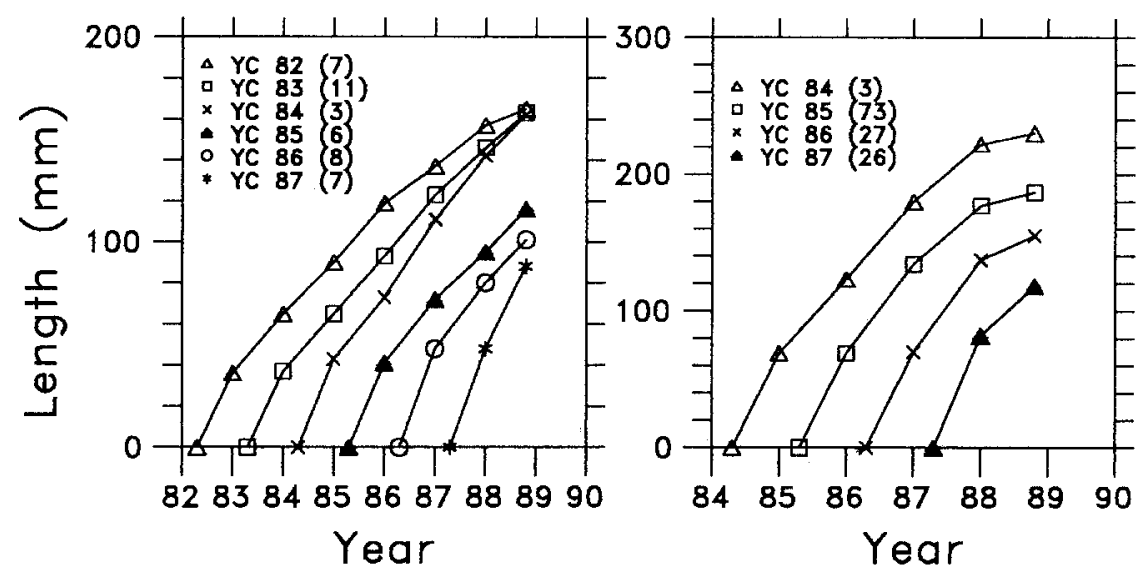

Figure 9. Growth of roach ("Triotto", left) and perch (right) in the North Basin. Mean length at full years except 1989, year classes 1982-1987 for roach and 1984-1987 for perch. Numbers in brackets indicate sample size

north of the Alps (Müller 1983). It should be pointed out that this species was caught only in the North Basin. However, the data are too scarce to provide any reliable clue regarding the age structure of the Lake Lugano stock.

Growth of perch was found to be similar in both basins. Perch (Fig. 9) reached a maximum length of $260-280 \mathrm{~mm}$. In comparison with perch in eutrophic Central European lakes (e.g. Lang \& Lang 1983), perch in Lake Lugano grew quite slowly, and even slower than in oligotrophic Lake Maggiore (Polli 1986). There is no obvious reason for this since the food base in Lake Lugano is plentiful. As with the other species, inferences about age structure or year class strength cannot be made. 


\section{Conclusions}

The results on the fish fauna of Lake Lugano presented here demonstrate that further investigations, preferably at regular intervals, are necessary in order to adequately describe relevant population parameters such as reproduction, growth and mortality of the most important fish species, and to analyze the structure and dynamics of the pelagic food web in this lake. In particular, the processes that impair normal development of an ecologically balanced fish community should be evaluated, and ways for rapid improvement should be sought. This requirement may be exemplified by two important questions: What is the effect of abnormally low oxygen concentration in the South Basin (e.g. less than $4 \mathrm{mgl}^{-1}$ at all depths in February 1989, Fig. 5) on the fish populations? Secondly, what is the reason for the near total absence of fish observed in the bays of Porlezza, Capolago and Agno (Fig. 3)? The hypothesis that this resulted from the continued discharge of partially treated sewage water into these bays remains to be tested.

After a long period of indiscriminate stocking activities, the time has come to make decisions regarding the future development of the fish fauna of Lake Lugano. First priority should be given to the rapid restoration of a moderate trophic state that would allow all fish species present to thrive and to reproduce in the lake. The envisaged - although currently slow - improvement of the trophic state of Lake Lugano in the coming years fits well into this concept. Fishery management activities should be guided by determined objectives involving all major fish species and taking into account the conservation of native species. Further measures aimed at directly and rapidly improving critical environmental conditions, e.g. the low oxygen concentration in the South Basin, will have to be evaluated according to the actual development of the lake in coming years.

\section{ACKNOWLEDGEMENTS}

We are greatly indebted to B. Polli and the fish wardens of Lake Lugano for field assistance, and to J.C. Pedroli, B. Zaugg and A. Kirchhofer for providing growth data. The Biblioteca Cantonale in Bellinzona made available some of the old literature. B. Germann, C. Grieder and M. Mbwenemo Bia helped with sample processing. We thank W. Nellen, J. Perlinger and B. Polli for critically reviewing the manuscript.

\section{REFERENCES}

Antonini, M., 1948. Popolazione ittica del Ceresio. Acquicoltura tic. 32:82-84.

Baldi, E., J. Florin, L. Pirocchi \& V. Tonolli, 1948. Resultate aus Versuchen über künstliche Befruchtung und scheinbare künstliche Parthenogenese beim Agone. Schweiz. Fischerei-Z. $56: 113-120$.

Barbieri, A., B. Polli, G. Righetti und M. Simona, 1989. Die trophische Entwicklung des Luganersees unter dem Einfluss der Sanierungsmassnahmen. VSA-Verbandsbericht Nr. 404.

Berg, L. S., 1933. Übersicht der Verbreitung der Süsswasserfische Europas. Zoogeographica 1:107208.

Berg, L. S., 1948. Freshwater Fishes of the U.S.S.R. and Adjacent Countries. Moskau-Leningrad (Israel Progr. Sci. Transl., Jerusalem, 1962-65). 
Canestrini, G., 1865. Prospetto critico dei Pesci d'acqua dolce d'Italia. Modena.

De Filippi, 1844. Pesci finora osservati in Lombardia. Notizie naturali e civili su la Lombardia, vol. I.

EAWAG, 1990. Untersuchung des Fischbestandes im Luganersee. Contract No. 4774 by the Dipartimento dell'Economia Pubblica, Cantone Ticino.

Ehrenberg, J. E., 1984. Dual-beam target strength system. Acoustic systems for the assessment of fisheries. FAO Fish Circ. 778:71-80.

Fatio, V., 1882-1890. Faune des Vertébrés de la Suisse. Vol. IV. Histoire naturelle des poissons, part. I. Vol. V. part II. H. Georg, Genève et Bâle.

Fuhrmann, O. e E. Pelloni, 1938. L'ittiofauna svizzera con considerazioni sui pesci del versante ticinese. Acquicoltura tic. 22(3-4):17-31.

Ghidini, A., 1910. L'ittiofauna del Cantone Ticino nel 1910. (Fauna ticinese, - IX). Boll. Sco. tic. sci. nat. 6:65-74.

Giussani, G. and T. Ruffoni, 1985. Biology and growth of the Bleak (Alburnus alburnus alborella) in two Lakes (Lago Maggiore and Lago die Varese) characterized by a different trophic level. Mem. Ist. Ital. Idrobiol. 43:147-159.

Gjernes, T., 1979. A Portable Midwater Trawling System For Use in Remote Lakes. Fish and Marine Serv. Tech. Rep. No. 888. Fish. and Environment, Canada.

Grimaldi, E., 1992. Lago Maggiore; Rapporto Informativo Annuale 1991. Fishery Commission for the Italian-Swiss Waters. Pallanza.

Heckel, J. und R. Kner, 1858. Die Süsswasserfische der Oesterreichischen Monarchie. Leipzig.

Heuscher, J., 1905. Das Massensterben der Agoni im Luganersee (Ceresio). Schweiz. Fischerei-Z. 13(5)/Beilage.

Kaufmann, H., 1960. Der Stör in der Schweiz. Historisch-geografische Monographie über das Auftreten des Störs in der Schweiz. Schweiz. Fischerei-Z. 68:209-210.

Lang, B. et C. Lang, 1983. Effects combinés de la pêche et de l'eutrophisation sur la perche (Perca fluviatilis L.) dans les eaux vaudoises du Léman. Schweiz. Z. Hydrol. 45(2):480-494.

Lavizzari, 1859-1863. Escursioni nel Cantone Tícino. Lugano.

Love, R. H., 1977. Target strength of an individual fish at any aspect. J. Acoust. Soc. Am. 62(6): $1397-1403$.

LSA, 1990. Dati idronaut 1989 (Raw Data). Laboratorio Studi Ambientali, Cantone Ticino. Bellinzona.

Monti, M., 1846. Ittiologia della Provincia e Diocesi di Como. Almanacco di Como.

Monti, M., 1864. Notizie dei pesci delle provincie di Como e Sondrio e del Cantone Ticino. Como. Müller, R., 1983. Das Weissfischproblem im Alpnacher See. Fischwirt 33(5):37-39.

Müller, R., 1992. Trophic state and its implications for natural reproduction of salmonid fish. Hydrobiologia (in press).

Pavesi, P., 1871-1872. I pesci e la pesca nel Cantone Ticino. Veladini \& Co, Lugano.

Pedraita, A., 1956. Die Fischereiverhältnisse im Kanton Tessin. Schweiz. Fischerei-Z. 64:192-195.

Pedroli, J.-C., B. Zaugg \& A. Kirchhofer, 1991. Verbreitungsatlas der Fische und Rundmäuler der Schweiz. Centre Suisse de Cartographie de la Fauna, Neuchâtel.

Polli, B., 1986. Studio idrobiologico e ittiologico delle Bolle di Magadino, Campagna 1986. Laboratorio Studi Ambientali, Cantone Ticino, Bellinzona.

Schinz, H.R., 1836. Naturgeschichte und Abbildungen der Fische. J. Brodtmanns lithogr. KunstAnstalt, Schaffhausen.

Steinmann, P., 1936. Die Fische der Schweiz. Sauerländer \& Co., Aarau.

Steinmann, P., 1948. Schweizerische Fischkunde. Sauerländer \& Co., Aarau.

Tonn, W., 1990. Climate change and fish communities: A conceptual framework. Trans. Am. Fish Soc. $119: 337-352$.

Received 3 July 1992;

Revised manuscript accepted 28 July 1992. 